\title{
EQUILIBRIUM-LINE ALTITUDES, MASS BALANGE, AND JULY FREEZING-LEVEL HEIGHTS IN THE CANADIAN HIGH ARGTIC
}

\author{
By R. S. BRAdley \\ (Department of Geology and Geography, University of Massachusetts, Amherst, \\ Massachusetts 0 I 002 , U.S.A.)
}

\begin{abstract}
Equilibrium-line altitudes on the White Glacier, Axel Heiberg Island, and the north-west sector of the Devon Ice Cap are shown to be closely related to mean July freezing-level heights at nearby upper-air weather stations. An inverse relationship between July freezing-level heights and mass balance on the Devon Ice Cap is also shown. Reasons for such correlations are suggested and some limitations of the relationship are outlined. Recent lowering of the freezing level in July is discussed in relation to the theoretical "steady-state" equilibrium-line altitudes in the Canadian high Arctic. It is suggested that positive mass-balance years have predominated over a large part of northern Ellesmere Island and northcentral Axel Heiberg Island since r963, and some glaciological evidence supporting this hypothesis is given.

RÉsumé. Altitude des lignes d'équilibre, bilans et hauteurs des niveaux de gel en juillet dans le haut Arctique Canadien. On montre que les altitudes des lignes d'équilibre du White Glacier dans Axel Heiberg Island, et le secteur Nord-Ouest de la calotte de Devon sont en étroite relation avec les hauteurs du niveau moyen du gel en juillet dans les stations climatologiques du voisinage. On trouve également une relation inverse entre les hauteurs du niveau de gel en juillet et le bilan de la calotte glaciaire de Devon. On suggère quelques explications à ces relations et on en esquisse quelques limites. Le récent abaissement du niveau du gel en juillet est discuté par référence aux altitudes théoriques de la ligne d'équilibre d'un "stade stable" dans le haut Arctique Canadien. On suggère que les années de bilan positif ont prédominé depuis r 963 sur une large part de l'Ellesmere Island du Nord et du Centre et du Nord de l'Axel Heiberg Island; quelques observations glaciologiques corroborant ces hypothèses sont présentées.
\end{abstract}

Zusammenfassung. Höhen der Gleichgewichtslinie, Massenhaushalt und fuli-Frostgrenze in der kanadischen Hoch-Arktis. Es wird gezeigt, dass die Höhen der Gleichgewichtslinie auf dem White Glacier, Axel Heiberg Island, und auf dem nordwestlichen Sektor des Devon Ice Cap eng mit den Höhen der mittleren JuliFrostgrenze über nahegelegenen Wetterstationen für die höhere Atmosphäre zusammenhängen. Ebenso wird eine inverse Beziehung zwischen den Höhen der Juli-Frostgrenze und dem Massenhaushalt auf dem Devon Ice Cap nachgewiesen. Gründe für diese Korrelationen werden vorgeschlagen und einige Beschränkungen des Zusammenhanges dargelegt. Das neuerliche Absinken der Frostgrenze im Juli wird im Hinblick auf die Höhen der theoretischen "stationären" Gleichgewichtslinie in der kanadischen Hoch-Arktis diskutiert. Es wird vermutet, dass seit 1963 auf einem grossen Teil der nördlichen Ellesmere Island und der nördlichen zentralen Axel Heiberg Island Jahre mit positivem Massenhaushalt überwogen; einige glaziologische Fakten zur Stützung dieser Hypothese werden angeführt.

\section{INTRODUCTION}

Over much of the Canadian Arctic Archipelago, surface temperatures are below $0^{\circ} \mathrm{C}$ from September to May (i.e. the $o^{\circ} \mathrm{C}$ isotherm or freezing level does not rise above the surface). The freezing level reaches a maximum elevation in July, and hence changes in the mean elevation of this surface can greatly influence the area of snow and ice affected by melting. With freezing levels near the ground surface, sensible heat exchange is low and receipts of long-wave radiation are reduced, resulting in less energy available for melting (Paterson, I969).

The height of the freezing level also determines the relative proportions of precipitation reaching the surface as rain or snow. As the elevation of the freezing level lowers, the percentage of precipitation falling as snow at the surface increases; when the freezing level is below approximately $250 \mathrm{~m}, 50 \%$ of the precipitation at the surface is in the form of snow. This has been shown for both mid-latitudes (Murray, I952, 1959) and Arctic regions (personal communication from R. G. Barry). By controlling the altitudinal zonation of rain and snow during the peak of the ablation season, the height of the July freezing level also has an important influence on surface albedo which remains high where summer snowfall occurs and thus further diminishes the energy available for melting. 


\section{ELA, MASS BALANCE AND THE FREEZING LEVEL}

In any balance year the equilibrium line is the boundary between the zone of net accumulation and the zone of net ablation on a glacier. The height of the equilibrium line is thus an integrated measure of the relative amounts of accumulation and ablation throughout the mass-balance year. In negative mass-balance years the equilibrium line altitude (ELA) will be high, while in positive mass-balance years the reverse is true. By examining variations of climatic parameters with changes in equilibrium line altitude, the principal climatic influences on the ELA can be determined.

Few records of equilibrium line altitude variations are available for Canadian Arctic. However, on the White Glacier, Axel Heiberg Island (Figure I) ELA measurements have been kept for about a decade (Müller, I966, I967, I968, г970). The White Glacier extends from $75 \mathrm{~m}$ to $\mathrm{I} 400 \mathrm{~m}$ a.s.l., with an average gradient of $\mathrm{I}$ in $\mathrm{Io}$ (Adams, I966). Surface and upperair climatological data are available for Isachsen (lat. $78^{\circ} 47^{\prime} \mathrm{N}$., long. $103^{\circ} 32^{\prime} \mathrm{W}$.), $300 \mathrm{~km}$ to the south-west, and Eureka (lat. $80^{\circ}$ oo' N., long. $85^{\circ} 65^{\prime}$ W.), I I o km to the north-east. Table I shows correlation coefficients between the White Glacier ELA and various climatic parameters. The equilibrium-line altitude is poorly correlated with winter precipitation, particularly at Eureka, which is situated in the lee of the Axel Heiberg mountains. However,

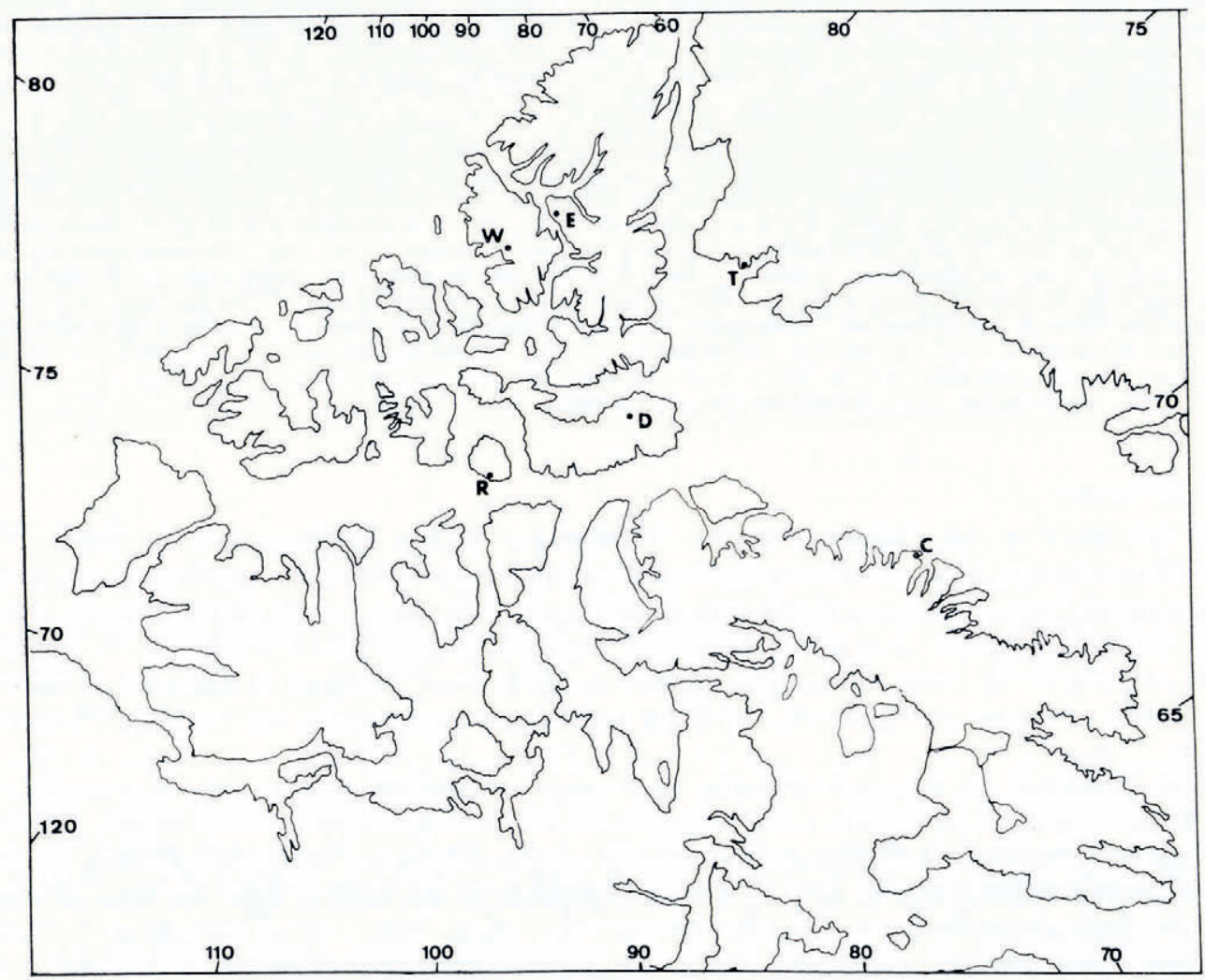

Fig. I. Location of places mentioned in text. $E=$ Eureka, Ellesmere Island; $W=$ White Glacier, Axel Heiberg Island; $R=$ Resolute, Cornwallis Island; $D=$ Devon Ice Cap, Devon Island; $C=$ Clyde, Baffin Island; $T=$ Thule, Greenland. Note: only the Devon Ice Cap is stippled. 
very high correlations (significant at $<1 \%$ level) exist between the ELA and July freezing levels* at both Isachsen and Eureka. Mean summer (June, July and August) freezing levels are less highly correlated with ELAs.

Table I. Correlation coefficients between climatic Parameters measured at Eureka and Isachsen and the Ela on White Glacier, Axel Heiberg Island, I959/6o тo 1968/69 (EXCLUDing 1967/68)

Isachsen winter (September-May) precipitation Eureka winter (September-May) precipitation

Average winter precipitation of Eureka and Isachsen Correlation coefficient

Average summer (June-August) freezing level at Isachsen

\section{$0.5^{2}$}

0. 1 I

Average summer (June-August) freezing level at Eureka

0.43

0.70

0.62

0.67

0.94

0.9 I

Average July freezing level at Eureka and Isachsen

Average July freezing level at Isachsen

0.97

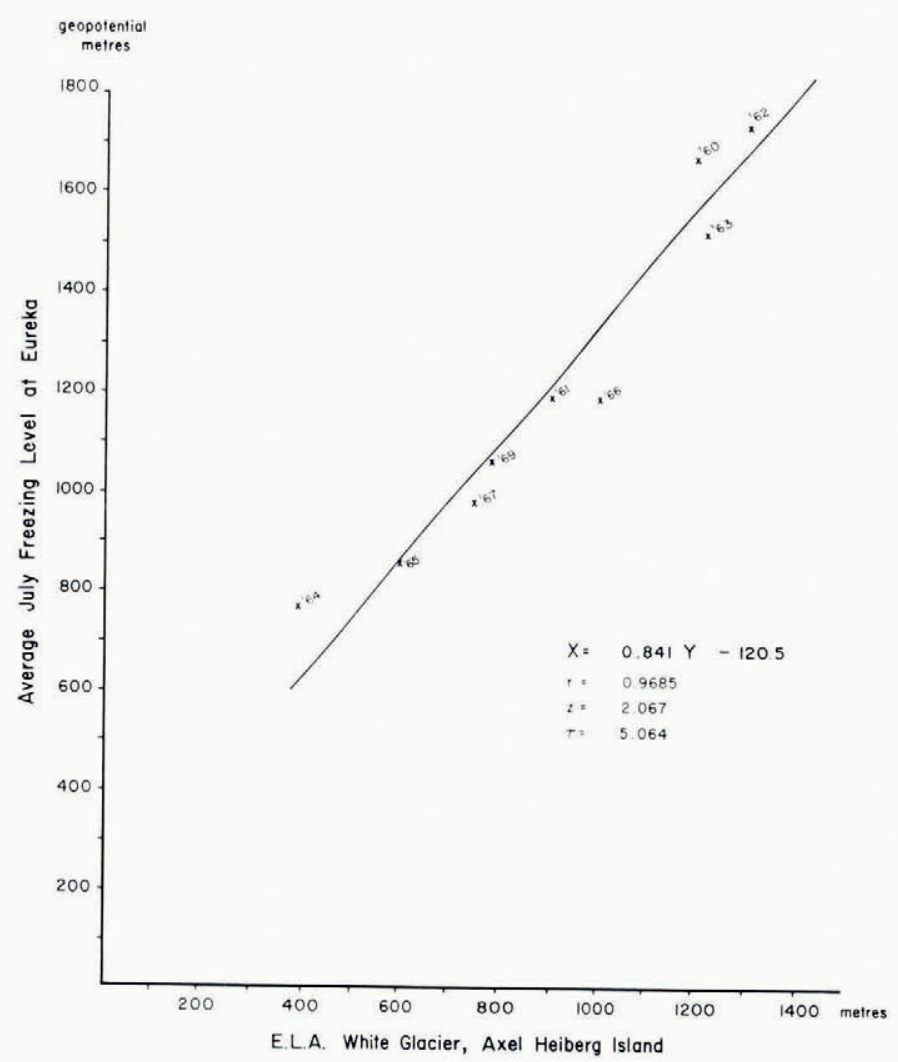

Fig. 2. Equilibrium-line altitudes on the White Glacier, Axel Heiberg Island, in relation to July freezing-level heights at Eureka (1959/6o to $1968 / 69$; no data for $1967 / 63)$. Geopotential metre $\approx 0.9^{8}$ metres. Freezing level for July 1960 related to ELA for $1959 / 60$, etc. (White Glacier data from Müller, $1966,1967,1968$ and 1970 .)

* Freezing levels at Canadian upper-air stations are coded by the Atmospheric Environment Service, Downsview, Ontario, Canada. In this study, average July freezing levels at oo.oo GMT were the average of codes o, I 
Figure 2 illustrates the relationship between July freezing-level height at Eureka and ELAs on the White Glacier, Axel Heiberg Island. Although the record is short, it is clear that the height of the freezing level in July has an important influence on the equilibrium-line altitude of the glacier. A similar analysis was carried out using the record of ELAs on the northwestern sector of the Devon Ice Cap (Koerner, I970 and personal communication), and July freezing levels at Resolute, $350 \mathrm{~km}$ to the west (Fig. 3a). Again a strong correlation

(a)

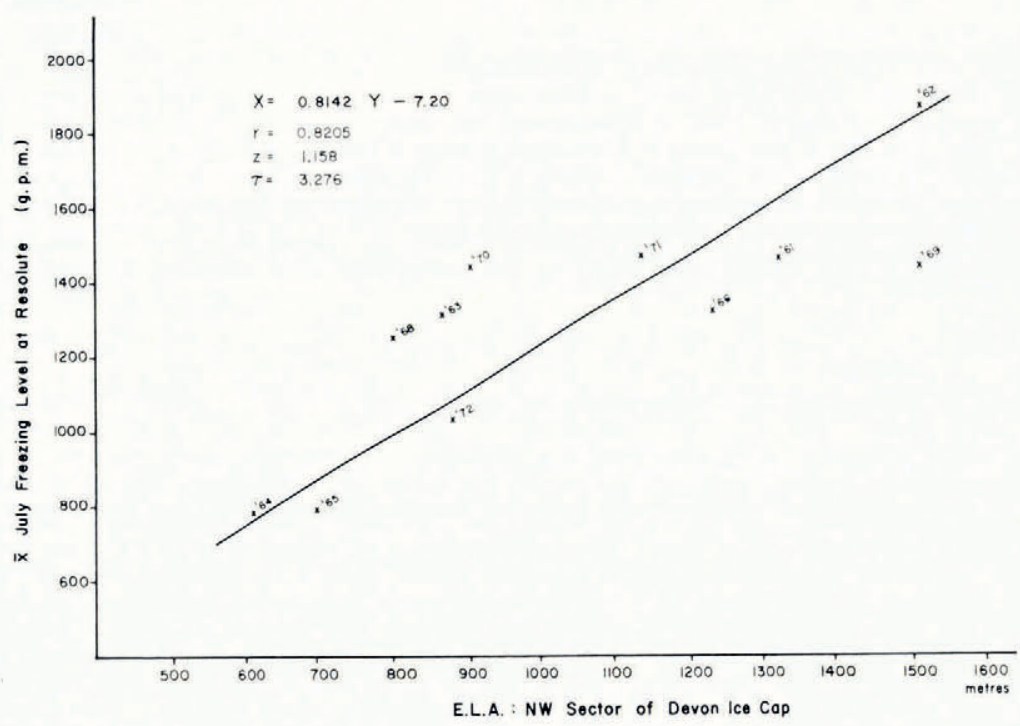

(b)

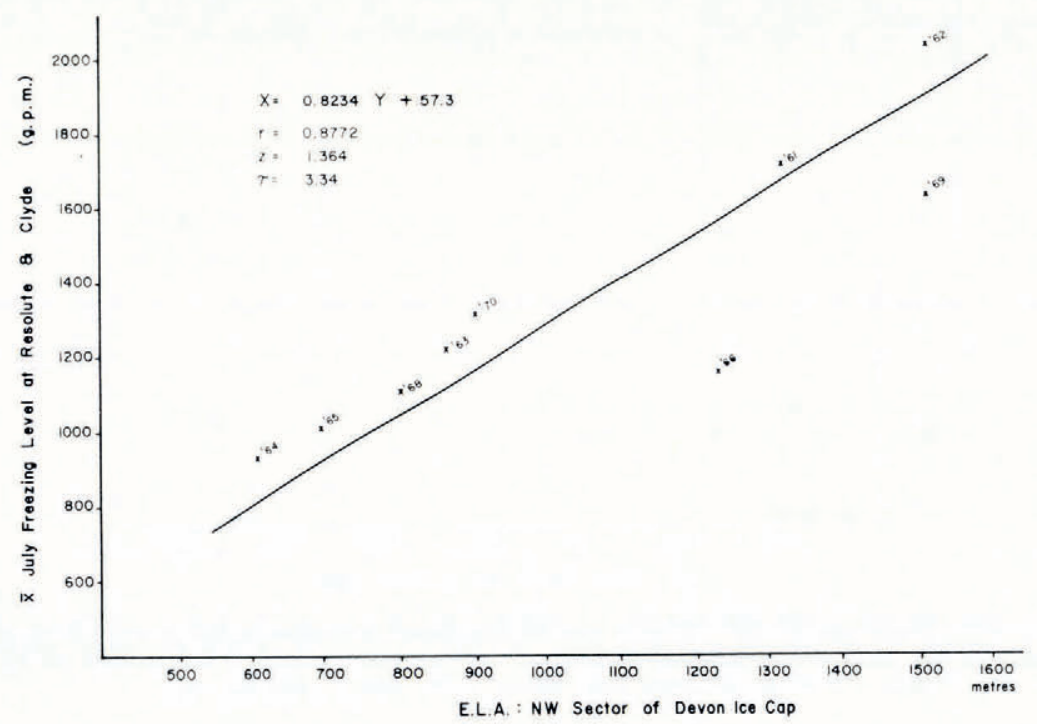

Fig. 3. Equilibrium-line altitudes on the Devon Ice Cap, north-west sector, in relation to: (a) July freezing level heights at Resolute (Cornwallis 1sland), Ig6o/6I to $197 \mathrm{I} / 72:(b)$ an average of July freezing level heights at Resolute and Clyde, (Baffin Island), Ig6I/62 to I970/7I. The ELA for 1967 has been omitted because it is based on fewer observations than other years. (Devon Island data from Koerner, I97o and personal communication, 1973.) 
(significant at $<\mathrm{r} \%$ level) is indicated, though again the small number of points requires caution in interpretation. However, in view of the importance of the freezing level (discussed above), it is not difficult to see a meaningful physical relationship between freezing-level height and equilibrium-line altitude. Furthermore, the ELA on the Devon Ice Cap is closely related to glacier mass balance (Koerner, 1970, fig. 8) and so the relationship between mass balance and July freezing-level height was also examined (Fig. 4a). As expected, there is a negative relationship (statistically significant at $<\mathrm{r} \%$ level), with low freezing levels corresponding to positive mass-balance years. Both figures, although based on limited field observations and upper-air data a considerable distance from the ice bodies, suggest that July freezing-level height acts as a major control on the mass balance and ELA of these high Arctic ice bodies. Upper-air soundings closer to the ice bodies may improve the relationships even further. This is suggested, in fact, by the higher correlation coefficients between the average of July freezing levels at Resolute and Clyde and the ELA and mass balance on the north-west Devon Ice Cap (the ice cap lies between these two upper-air stations) (Figs $3 \mathrm{~b}$ and $4 \mathrm{~b}$ ). However, the Clyde station closed in 1970 and so today the nearest upper-air station to the ice cap is Resolute. It is very likely that upper-air data from Thule would also improve the prediction of ELAs on the Devon Ice Cap. However, unlike the Canadian stations, Thule is operated entirely by the U.S. Weather Bureau and freezing levels are not explicitly analysed and published. Freezing levels could normally be obtained from significant-level data but these are not available for Thule. Consequently freezing levels at Thule must be obtained either from interpolation between standard pressure levels (which is not a very reliable method) or from examination of individual daily soundings for the relevant period. Because of the cost and inherent problems of such data reduction it was decided that Canadian stations which are closest to the Devon Ice Cap would be used (Fig. I) and the results clearly indicate that an improvement in the relationship is achieved by the use of both Clyde and Resolute data. It would be of interest for upper-air soundings to be taken directly above these ice bodies to see what further information might be gained from observations in the immediate vicinity rather than from stations hundreds of kilometres away.

\section{LiMITATIONS OF THE REGRESSIONS}

Although a plot of ELAs on these two ice bodies and adjacent upper-air data indicates a simple linear relationship based on Io or I 2 points there are physical constraints to be considered which place limitations on the regression. For example, in a very cold summer (low July freezing level) the firn line will be lowered. If the following summer is warm and melting occurs, much of the melt may be absorbed by the porous firn resulting in a less negative balance than the freezing level suggests. This, in fact, is the case for the warm summer of I 966 (preceded by two extremely cold summers) and ig69 (preceded by the cold summer of i 968 ).

Adjusting the ELA downward to account for this would bring both points closer to the regression line for the other years (see Fig. 3 b). Similarly, the mass balance for these years would appear to be lower than is actually the case, as shown by the balance year i $965-66$ (Fig. 4b). Adjusting this upward (i.e. towards a more positive balance) would bring the point closer to the regression line for the other years. Thus, although there are glaciological considerations to be taken into account with the linear relationship outlined above these actually appear to reinforce the connection between upper-air data and glacial mass balance.

\section{REGENT FREEZING LEVEL GHANGES}

In view of the fact that there appears to be a close relationship between annual equilibriumline altitudes in the high Arctic and the corresponding mean July freezing levels, it is of interest to consider recent freezing-level changes in the area in relation to the "steady-state" ELAs, 
estimated from the I : 250 ooo topographic maps of the Canadian high Arctic (i.e. north of lat. $72^{\circ}$ N.) (Miller and others, I975). As a result of large falls in July freezing levels throughout the Canadian archipelago since 1963 (Bradley, 1973), the mean July freezing levels 1963-72 have been below the "steady-state" ELAs over large areas of northern and central Ellesmere Island and north-central Axel Heiberg Island. This suggests that during the period I $963-72$, a large upland area in the Canadian high Arctic experienced predominantly positive

(a)

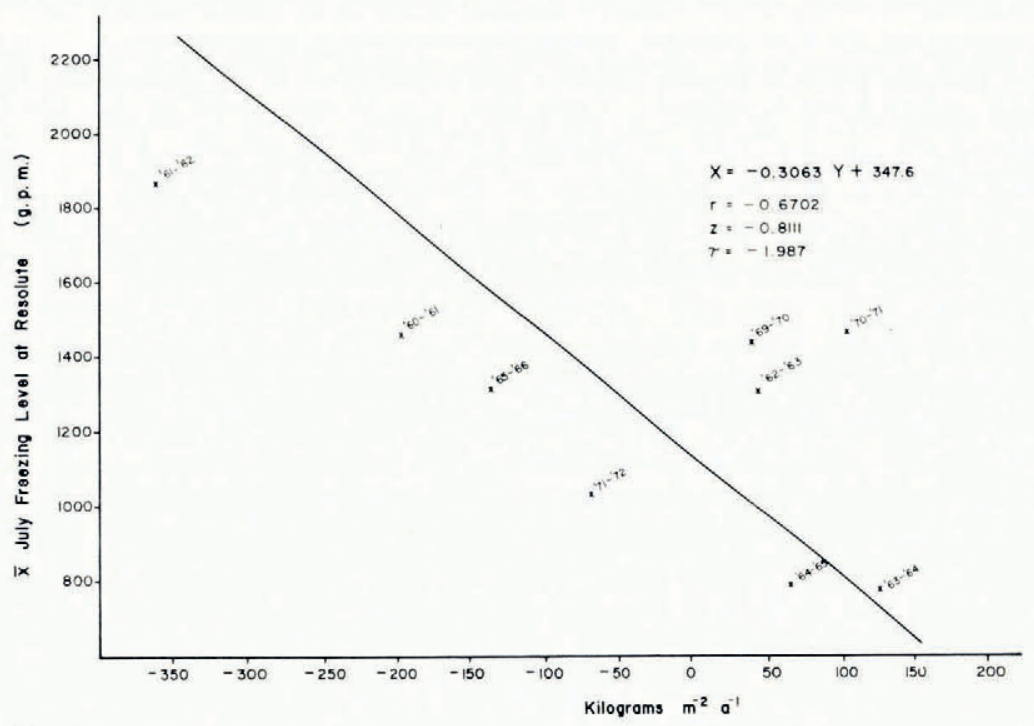

(b)

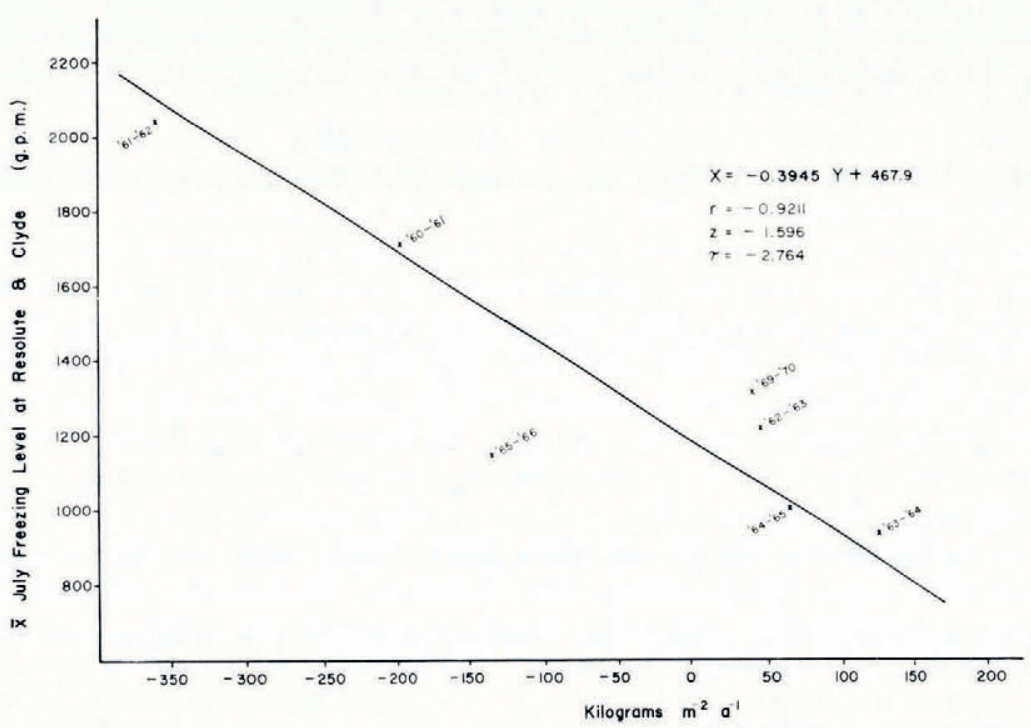

Fig. 4. Mass balance on the Devon Ice Cap, north-west sector, in relation to: (a) Fuly freezing level heights at Resolute (Cornwallis Island), 1960 to $1965 / 66$ (no data for the years $1966 / 67$ to $1968 / 69$ ) and $1969 / 70$ to $1971 / 72 ;(b)$ an average of July freezing-level heights at Resolute and Clyde (Baffin Island), I960/6I to 1965/66 and I969/70. No mass-balance data for $1966 / 67$ to $1968 / 69$ and no Clyde upper-air data after 1969/70. (Devon Island data from Koerner, 1970 and personal communication, 197.3.) 
mass-balance years. Unfortunately, no regular observations were made in this remote area during the last decade, but some support for this suggestion comes from the observations made by Hattersley-Smith (1972) on a traverse across the United States Range, northern Ellesmere Island in 1967 . He notes that the former percolation facies of the ice cap above $\mathrm{r} 800 \mathrm{~m} \mathrm{had}$ been changed to an almost dry-snow facies and the equilibrium line on the glaciers had been lowered to an elevation of about $900 \mathrm{~m}$ from a mean of about $\mathrm{I} 200 \mathrm{~m}$ in the years $1957-63$. This fall in the equilibrium-line altitude is similar to the recent decrease in mean July freezing level observed at Alert and Eureka (Bradley, 1973). Highly positive net budgets on the Gilman Glacier, northern Ellesmere Island, have also been noted by R. B. Sagar for the period $\mathrm{I}_{962-67}\left(c .+230 \times \mathrm{IO}^{6} \mathrm{~m}^{3} \mathrm{H}_{2} \mathrm{O}\right)$ (Hattersley-Smith, 1972$)$ and recent expansion and thickening of a small ice cap on north-eastern Ellesmere Island have been reported (HattersleySmith and Serson, 1973).

In interpreting the climatological and glaciological evidence it should be noted that, although there is a strong relationship between ELA, mass balance and July freezing-level variations over time, small-scale maps of mean July freezing levels over the period $1955^{-6} 3$ do not resemble the small-scale "steady-state" ELA maps in details. These differences may point to the influence of other macroscale climatic factors or may reflect the problems of mapping ELAs over large areas, and at a point in time when the ice bodies may not be in equilibrium with contemporary climate. If ice bodies represented on the I : 250 ooo maps are lagging in response to the post-I 880 warming trend, the estimated ELAs may be unrealistically low. However, as the recent freezing levels (1963-72) are below these estimated ELAs the predominance of positive mass-balance years over the last decade for a large part of northern Ellesmere and north-central Axel Heiberg Island is a reasonable assumption.

\section{Conclusion}

It has been shown that in recent years at the high Arctic sites examined, a strong relationship exists between equilibrium-line altitude, mass balance and the corresponding mean height of the freezing level in July of that year. If studies at additional sites support these relationships, they may provide a technique for estimating the broad-scale net balance over much of the Canadian high Arctic. In addition, estimates of palaeo-equilibrium-line altitudes may be interpreted more meaningfully in terms of this relationship. However, it should be noted that the two areas for which ELA records have been examined are representative of an area where winter precipitation amounts are small and the summer ablation period is relatively short (i.e. where mass exchange is low). In areas where winter precipitation amounts are higher and the ablation season longer, it is doubtful that the height of the July freezing level will be the major control on the equilibrium-line altitude.

\section{Acknowledgements}

This work was partly supported by a contract to J. T. Andrews from the Glaciology Division, Environment Canada, Ottawa, Canada. I would like to thank Drs R. M. Koerner, J. T. Andrews, L. D. Williams, G. H. Miller, R. G. Barry and J. H. England for helpful discussions and comments.

\section{MS. received 26 June 1974 and in revised form 21 August 1974}

\section{REFERENCES}

Adams, W. P. I966. Glaciology, No. I. Ablation and run-off on the White Glacier, Axel Heiberg Island, Canadian Arctic Archipelago. Axel Heiberg Island Research Reports, McGill University, Montreal. Jacobsen-McGill Arctic Research Expedition $1959^{-1962 .}$ 
Bradley, R. S. 1973. Recent freezing level changes and climatic deterioration in the Canadian Arctic Archipelago. Nature, Vol. 243, No. 5407, p. 398-400.

Hattersley-Smith, G. I 972 . Climatic change and related problems in northern Ellesmere Island, N.W.T., Canada. Acta Universitatis Ouluensis, Ser. A, No. 3, Geologica, No. 1, p. 137-48.

Hattersley-Smith, G., and Serson, H. 1973. Reconnaissance of a small ice cap near St. Patrick Bay, Robeson Channel, northern Ellesmere Island, Canada. Journal of Glaciology, Vol. 12, No. 66, p. 41 7-21.

Koerner, R. M. 1970. The mass balance of the Devon Island ice cap, Northwest Territories, Canada, $1961-66$. Journal of Glaciology, Vol. 9, No. 57, p. 325-36.

Loken, O. H. 1972. Growth and decay of glaciers as an indicator of long-term environmental changes. International Commission for the Northwest Atlantic Fisheries. Special Publication No. 8, p. 71-87.

Miller, G. H., and others. 1975. The glaciation level and lowest equilibrium line altitude in the high Canadian Arctic: maps and climatic interpretation, by G. H. Miller, R. S. Bradley and J. T. Andrews. Arctic and Alpine Research, Vol. 7, No. 2, p. 155-68.

Müller, F. 1966. Evidence of climatic fluctuations on Axel Heiberg Island, Canadian Arctic Archipelago. (In Fletcher, J. O., ed. Proceedings of the symposium on the Arctic heat budget and atmospheric circulation. . . 1966. Santa Monica, Calif., Rand Corporation, p. I35-56. (Memorandum RM-5233-NSF.))

Müller, F. 1967. Axel Heiberg Island. Ice, No. 23, p. 7-8.

Müller, F. 1968. Axel Heiberg Island. Ice, No. 26, p. 9-10.

Müller, F. I970. Axel Heiberg Island, N.W.T. Ice, No. 33, p. 8-9.

Müller, F., and others. 1963. Preliminary report i961-ig62, [by] F. Müller and others. Axel Heiberg Island Research Reports, McGill University, Montreal. [Jacobsen-McGill Arctic Research Expedition 1959-1962.]

Murray, R. 1952. Rain and snow in relation to the $1000-700 \mathrm{mb}$ and $1000-500 \mathrm{mb}$ thicknesses and the freezing level. Meteorological Magazine, Vol. 81, No. 955, p. 5-8.

Murray, R. 1959. Snow in relation to certain synoptic parameters. Metecrological Magazine, Vol. 88, No. 1049, p. $324^{-28}$.

Paterson, W. S. B. 1969. The physics of glaciers. Oxford, etc., Pergamon Press. (The Commonwealth and International Library. Geophysics Division.) 